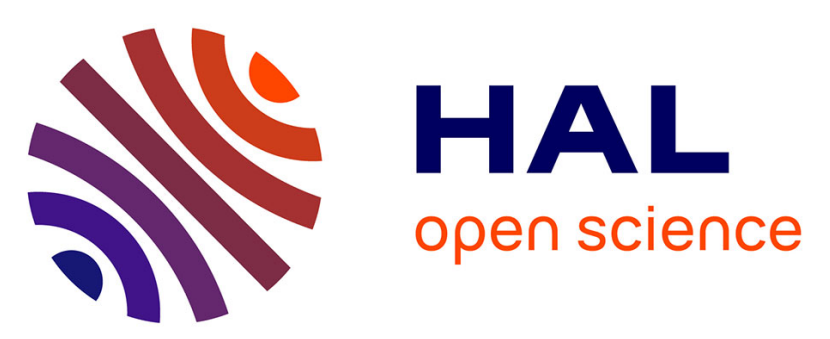

\title{
A Luciferase Reporter for Gene Expression Studies and Dynamic Imaging of Superficial Candida albicans Infections
}

\author{
Donatella Pietrella, Brice Enjalbert, Ute S Zeidler, Sadri Znaidi, Anna \\ Rachini, Anna Vecchiarelli, Christophe d'Enfert
}

\section{To cite this version:}

Donatella Pietrella, Brice Enjalbert, Ute S Zeidler, Sadri Znaidi, Anna Rachini, et al.. A Luciferase Reporter for Gene Expression Studies and Dynamic Imaging of Superficial Candida albicans Infections. Methods in Molecular Biology, 2012, Host-Fungus Interactions. Methods and Protocols, 845, pp.537546. 10.1007/978-1-61779-539-8_39. hal-02146745

\section{HAL Id: hal-02146745 \\ https://hal.science/hal-02146745}

Submitted on 7 Jun 2019

HAL is a multi-disciplinary open access archive for the deposit and dissemination of scientific research documents, whether they are published or not. The documents may come from teaching and research institutions in France or abroad, or from public or private research centers.
L'archive ouverte pluridisciplinaire HAL, est destinée au dépôt et à la diffusion de documents scientifiques de niveau recherche, publiés ou non, émanant des établissements d'enseignement et de recherche français ou étrangers, des laboratoires publics ou privés. 


\title{
A Luciferase Reporter for Gene Expression Studies and Dynamic Imaging of Superficial Candida albicans Infections
}

\author{
Donatella Pietrella, Brice Enjalbert, Ute Zeidler, Sadri Znaidi, \\ Anna Rachini, Anna Vecchiarelli, and Christophe d'Enfert
}

\begin{abstract}
Real-time imaging of fungal infections is becoming integral to the study of host-pathogen interactions, as it allows monitoring of the spatial and temporal progression of pathogen growth or of the host response in a single animal as well as reducing the number of animals used to obtain significant data. We present different applications of a novel luciferase reporter gene constructed from the coding sequences of the Candida albicans PGA59 gene, encoding a GPI-linked cell wall protein, and the Gaussia princeps luciferase gene. Upon addition of the coelenterazine substrate, light produced by the surface-exposed luciferase can be used to quantify gene expression from a variety of $C$. albicans promoters as well as monitoring cutaneous, subcutaneous, and vaginal infections.
\end{abstract}

Key words: Luciferase, Gaussia princeps, Imaging, Reporter, Gene fusion, Vulvovaginal candidiasis, Subcutaneous candidiasis, Superficial infection

\section{Introduction}

The study of host-pathogen interactions has recently benefited from the development of real-time imaging in small animals. Realtime imaging approaches take advantage of sensitive charge-coupled device (CCD) cameras to detect low levels of light emitted from luciferase reporters in vivo (1). They allow monitoring of the spatial and temporal progression of pathogen growth or of the host response in a single animal, making it possible to reveal the spread of pathogens to unexpected infection sites as well as significant variations in pathogen/host responses that can be masked by the heterogeneous 
behavior of individual animals. Moreover, real-time monitoring allows for a reduction in the number of animals required to generate statistically significant datasets (1).

Real-time imaging of Candida albicans infections has been pioneered by Doyle et al. $(2,3)$ who used the firefly luciferase gene expressed under the control of the C. albicans ENOI promoter to image different forms of C. albicans infections. This approach was successful in a vulvovaginal candidiasis model and allowed monitoring of the efficacy of an antifungal treatment. However, it suffered drawbacks, such as a limited permeability of hyphal cells to the firefly luciferase substrate, luciferin, and monitoring of disseminated candidiasis was unsuccessful.

In this chapter, we present a novel luciferase reporter whereby the naturally secreted Gaussia princeps luciferase (4) is targeted to the cell surface of C. albicans using the targeting signals of the C. albicans GPI-linked cell wall protein Pga59 (5) (Fig. la). This approach resulted in a highly sensitive reporter, referred to as gLUC59, localized at the cell surface and allowing detection of luciferase in intact yeast and hyphal cells even when expressed from a weak promoter (6). gLUC59 has been used successfully to monitor different forms of superficial C. albicans infections where the luciferase substrate coelenterazine can be directly delivered at the site of infection (Fig. 2). The efficacy of antifungal treatments, e.g., a $\beta$-glucan-conjugate vaccine and anti- $\beta$-glucan antibodies, against the development of different superficial C. albicans infections could be efficiently monitored $(6,7)$. Importantly, these studies showed that imaging superficial candidiasis with gLUC59-expressing C. albicans strains was more reliable than colony-forming unit (CFU) counts in assessing the extent and duration of these infections. However, it should be noted that monitoring systemic candidiasis has so far been unsuccessful when using C. albicans strains expressing the gLUC59 luciferase $(6,8)$.

Here, we present protocols for measuring C. albicans promoter activity in in vitro grown cells and monitoring of superficial, namely cutaneous, subcutaneous, and vaginal, C. albicans infections by imaging infected animals in the IVIS imaging system.

\section{Materials}

\subsection{Plasmids and C. albicans Strains}

2.2. Equipment
Plasmids and C. albicans strains of interest for imaging infections using the gLUC59 reporter are listed in Table 1 (see Note 1).

1. IVIS-200 ${ }^{\mathrm{TM}}$ imaging system (Xenogen Corporation).

2. Anesthesia chamber (Xenogen Corporation).

3. Flat-bottom black-wall 96-well plates (see Note 2).

4. Infinite M200 PRO multimode plate reader (Tecan). 


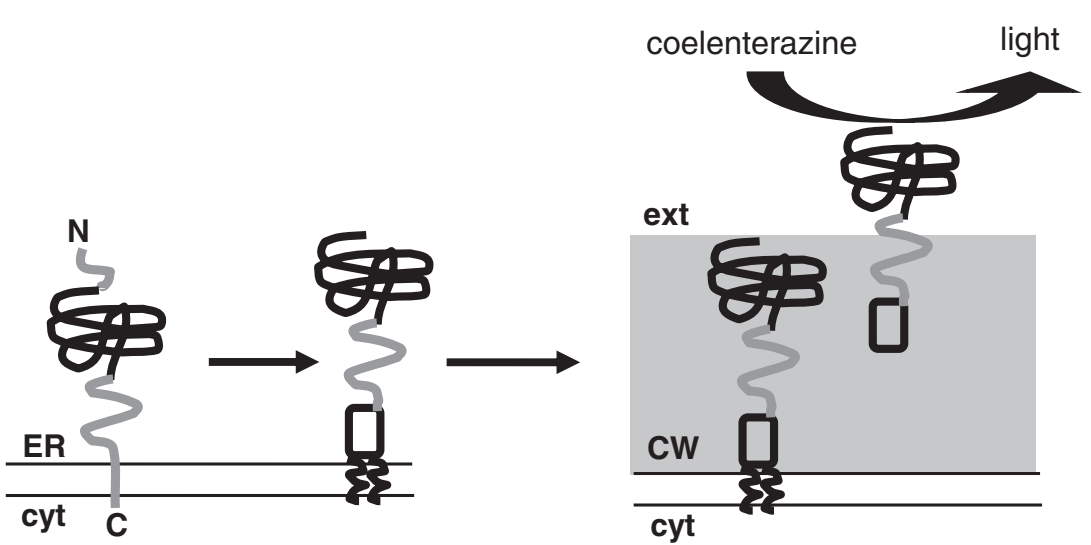

b

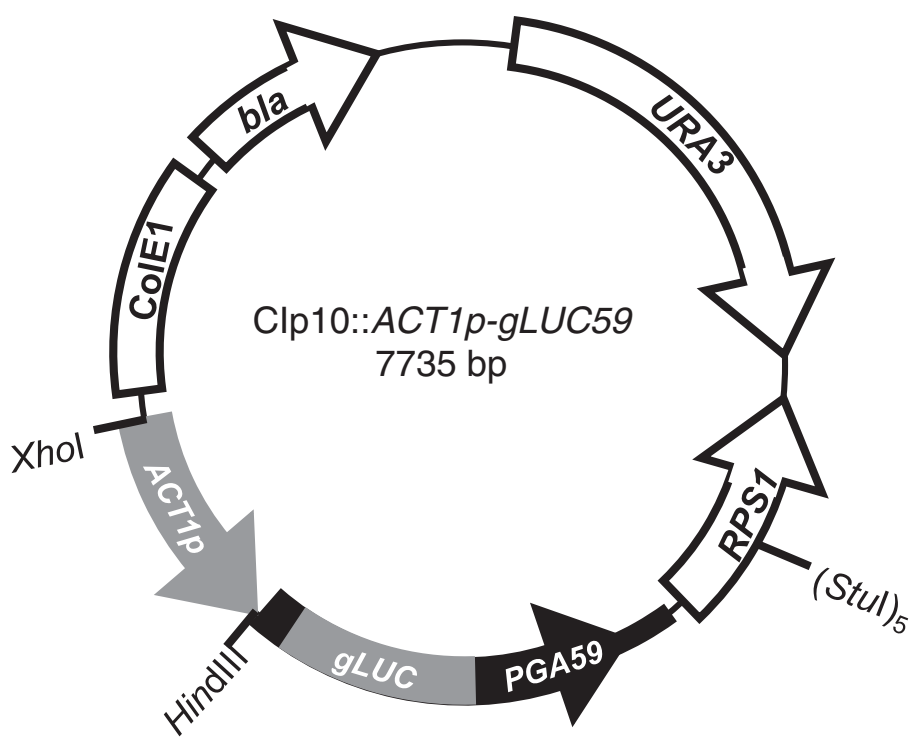

C

Hind I I I

A A T C T T CA A a g c t t T T TA A T A T G CA T T T

$\begin{array}{lllll}M & M & Q & F & S\end{array}$

Fig. 1. The cell surface exposed gLUC59 luciferase. (a) gLUC59 is synthesized as a fusion between the amino-terminal signal peptide of Pga59 (gray line), the Gaussia princeps luciferase (black line), and the mature and carboxy-terminal hydrophobic domains of Pga59 (gray line). Upon entry into the endoplasmic reticulum (ER), the Pga59 amino-terminal signal peptide and carboxy-terminal hydrophobic domain are cleaved and the protein is modified by addition of a glycophosphatidylinositol (GPI) anchor. The GPI-modified protein is then shuttled to the cytoplasmic membrane where the GPI anchor is processed, allowing gLUC59 to become anchored to cell wall (CW) $\beta$-glucans and exposed at the cell surface. Owing to the cell surface exposure of gLUC59, light is produced upon addition of coelenterazine to intact cells. (b) The CIp10::ACT1pgLUC59 vector is a derivative of the $C$. albicans Clp10 integrative vector (10) that harbors the $C$. albicans URA3 transformation marker (URA3; white arrow) and that, upon cleavage by Stul, integrates at the C. albicans RPS1 locus (RPS1; white arrow). A Xhol/Hindlll fragment encompassing the ACT1 promoter (ACT1p; gray arrow) was cloned upstream of the gLUC59 luciferase reporter gene. gLUC59 is a fusion between the $C$. albicans PGA59 gene (PGA59; black arrow) and the Gaussia princeps luciferase gene that has been adapted for efficient expression in $C$. albicans ( $g L U C$; gray box). Propagation of Clp10::ACT1p-gLUC59 is achieved in E. coli in the presence of ampicillin (bla; white arrow). The ACT1 promoter is easily exchanged by other promoter regions using a Xhol/Hindlll digest. (c) Nucleotide sequence at the junction between the ACT1 promoter and the gLUC59 reporter gene. Replacement of the ACT1 promoter (gray) by another promoter should ensure that an ATG start codon does not occur upstream and out-of-frame of the gLUC59 ATG start codon (black). 


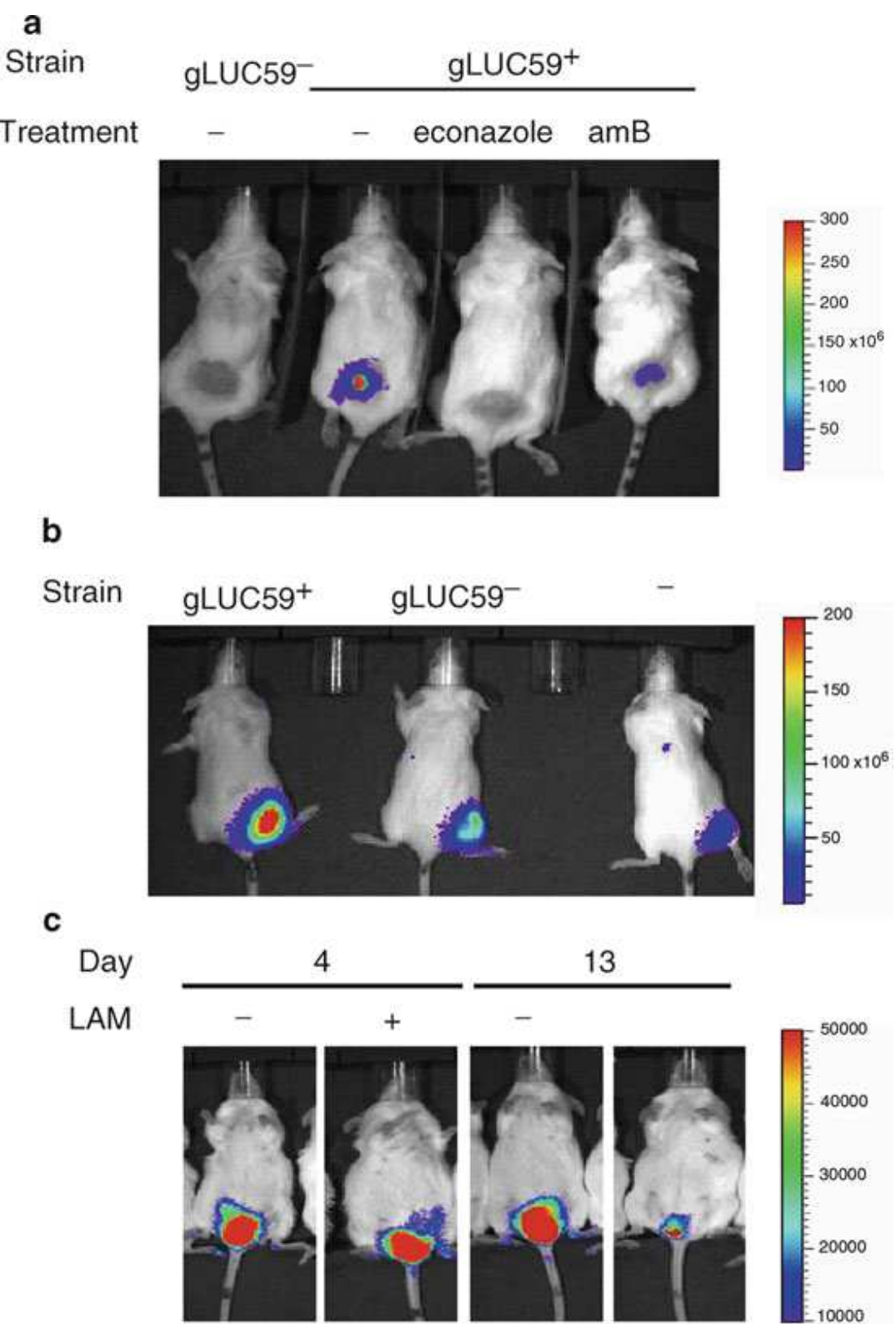

Fig. 2. In vivo imaging of mice infected with bioluminescent Candida albicans. (a) Cutaneous infection. Immunosuppressed mice were inoculated on a shaved and abraded skin area with $C$. albicans cells either expressing the gLUC59 cell surface exposed luciferase (gLUC59+) or not (gLUC59-). gLUC59+-infected mice were treated intraperitoneally with a placebo (-), econazole (10 mg/kg body weight), or amphotericin B (amB; $10 \mathrm{mg} / \mathrm{kg}$ ) every day post infection. At day 7 post infection, coelenterazine was deposited at the site of infection and mice were imaged in the IVIS-200 ${ }^{\mathrm{TM}}$ imaging system (Xenogen Inc.) (4). (b) Subcutaneous infection. Uninfected mice or mice inoculated subcutaneously with C. albicans cells expressing the gLUC59 cell surface exposed luciferase (gLUC59+) or not (gLUC59-) received a coelenterazine injection at the site of infection at 4 days post infection and imaged in the IVIS-200 ${ }^{\mathrm{TM}}$ imaging system (4). Background luminescence with control strains is frequently observed especially in inflamed regions. (c) Vaginal infection. Mice, previously treated with adjuvant (-LAM) or vaccinated with adjuvant plus a $\beta$-glucan conjugate (+LAM) were injected into the vaginal lumen with a suspension of $C$. albicans cells expressing the gLUC59 cell surface exposed luciferase. At days 4 and 13 post infection, mice received an intravaginal injection of coelenterazine and were imaged in the IVIS-200 ${ }^{\mathrm{TM}}$ imaging system (7). 


\section{Table 1}

\section{Plasmids and $C$. albicans strains}

\begin{tabular}{|c|c|c|c|c|}
\hline Plasmid & Promoter & & $\begin{array}{l}\text { C. albicans } \\
\text { strain }\end{array}$ & Reference \\
\hline CIp10::gLUC59 & - & & CA1399 & $(6)$ \\
\hline $\begin{array}{l}\text { CIpl0::gLUC59, } \\
\text { ura3::SAT1 }\end{array}$ & - & & & Lab collection \\
\hline CIp10::ACT1p-gLUC59 & ACTlp & Constitutive expression & CA1398 & $(6)$ \\
\hline $\begin{array}{l}\text { CIp10::ACT1p-gLUC59, } \\
\text { ura3::SAT1 }\end{array}$ & ACTIp & Constitutive expression & & Lab collection \\
\hline CIp10::TDH3p-gLUC59 & TDH3p & Constitutive expression & CEC2181 & Lab collection \\
\hline $\begin{array}{l}\text { CIpl0::TDH3p-gLUC59, } \\
\text { ura3::SAT1 }\end{array}$ & TDH3p & Constitutive expression & & Lab collection \\
\hline CIp10::ADH1p-gLUC59 & ADHIp & Constitutive expression & CEC2183 & Lab collection \\
\hline CIp10::TEF1p-gLUC59 & TEFIP & Constitutive expression & CEC2180 & Lab collection \\
\hline CIp10::EFT3p-gLUC59 & EFT3p & Constitutive expression & CEC975 & $(6)$ \\
\hline CIp10::TRR Ip-gLUC59 & $T R R I p$ & $\begin{array}{l}\text { Oxidative stress-induced } \\
\text { (strong) }\end{array}$ & CAl435 & $(6)$ \\
\hline CIp10::TRR Ip-gLUC59 & $T R X I p$ & $\begin{array}{l}\text { Oxidative stress-induced } \\
\text { (strong) }\end{array}$ & CAl 400 & $(6)$ \\
\hline CIp10::IPF9996p-gLUC59 & IPF9996p & $\begin{array}{l}\text { Oxidative stress-induced } \\
\text { (weak) }\end{array}$ & CAl 434 & (6) \\
\hline CIp10::HWP1p-gLUC59 & HWPIp & Hyphal-specific & CEC971 & (6) \\
\hline CIp10::ALS3p-gLUC59 & $A L S 3 p$ & Hyphal-specific & CEC939 & (9) \\
\hline CIp10::HSP70p-gLUC59 & HSP7Op & Heat shock responsive & CEC2134 & Lab collection \\
\hline CIp10::MKC1p-gLUC59 & MKClp & $\begin{array}{l}\text { PKC cell integrity pathway } \\
\text { induced (weak) }\end{array}$ & CEC2136 & Lab collection \\
\hline CIp10::UTR2p-gLUC59 & UTR $2 p$ & $\begin{array}{l}\text { Calcineurin pathway } \\
\text { induced }\end{array}$ & CEC2138 & Lab collection \\
\hline CIp10::CRZ1p-gLUC59 & CRZIp & $\begin{array}{l}\text { Calcineurin pathway } \\
\text { induced }\end{array}$ & CEC2140 & Lab collection \\
\hline
\end{tabular}

\subsection{Media} and Reagents
1. YPD: 1\% yeast extract (Difco), 2\% Bacto-peptone (Difco), 2\% D-glucose; autoclave $10 \mathrm{~min}$ at $120^{\circ} \mathrm{C}$; add $1.5 \%$ Bacto-agar for solid medium.

2. 1 M coelenterazine (Molecular Probes; see Note 3) in methanol.

3. $500 \mu \mathrm{g} / \mathrm{mL}$ coelenterazine (Synchem; see Note 3) in 1:9 methanol:PBS. 


\subsection{Animals (see Note 4)}

4. $1 \mathrm{mg} / \mathrm{mL}$ coelenterazine (Synchem; see Note 3 ) in $1: 4$ methanol:PBS.

5. Estradiol valerate sesame oil.

6. LA buffer: $0.5 \mathrm{M} \mathrm{NaCl}, 0.1 \mathrm{M} \mathrm{KH}_{2} \mathrm{PO}_{4} \mathrm{pH}$ 6.7, 1 mM EDTA, $0.6 \mathrm{mM} \mathrm{NaN}_{3}, 1 \mathrm{mM}$ phenylmethylsulfonide fluoride cocktail (Boehringer).

Six-week-old female CDl mice (Harlan), housed in groups of 4-6 mice per cage, were allowed to acclimatize for 1 week prior to experimentation. Animals were maintained under specific pathogen-free (SPF) conditions that included testing sentinel animals for unwanted infections; according to the Federation of European Laboratory Animal Science Association standards, no infections were detected.

\section{Methods}

\subsection{Measurement of Luciferase Activity from In Vitro Grown Candida albicans Cells Expressing gLUC59 Constructs (see Note 5)}

1. Using C. albicans cells from an overnight culture, inoculate two $20 \mathrm{~mL}$ cultures of YPD to OD 0.1.

2. Allow cells to grow for $2 \mathrm{~h}$ at $30^{\circ} \mathrm{C}$ with shaking.

3. Take a $1 \mathrm{~mL}$ sample from both cultures, measure the $\mathrm{OD}_{600}$, and keep on ice.

4. If examining fungal cell responses to a compound, add the compound of interest to one of the two cultures and then continue incubation of both cultures at $30^{\circ} \mathrm{C}$.

5. Collect $1 \mathrm{~mL}$ samples from the untreated and treated cultures at different time points, measure the $\mathrm{OD}_{600}$, and keep on ice.

6. Centrifuge $1 \mathrm{~mL}$ samples for $3 \mathrm{~min}$ at $3,000 \times g$ at $4^{\circ} \mathrm{C}$ in an Eppendorf centrifuge.

7. Resuspend cells in $500 \mu \mathrm{L}$ cold LA buffer and centrifuge for 3 min at $3,000 \times g$ at $4^{\circ} \mathrm{C}$.

8. Resuspend cells in $250-500 \mu \mathrm{L}$ cold LA buffer to obtain the same cell/volume concentration in all samples and keep on ice (see Note 6).

9. Put $100 \mu \mathrm{L}$ of each sample in duplicate into a flat-bottom black-wall 96-well plate.

10. Add $100 \mu \mathrm{L}$ of freshly made $2 \mu \mathrm{M}$ coelenterazine in LA buffer to each well. Pipet up and down once.

11. Measure immediately in a luminometer (e.g. Infinite M200 PRO plate reader; see Note 7). 
3.2. Real-Time

Imaging of C. albicans

Cutaneous Infection

(see Note 8)

3.3. Real-Time

Imaging of C. albicans

Subcutaneous

Infection

\subsection{Real-Time \\ Imaging of Vaginal \\ Candidiasis}

1. Three days prior to infection, immunosuppress mice by intraperitoneal injection of cyclophosphamide $(150 \mathrm{mg} / \mathrm{kg})$.

2. One day prior to infection, inoculate a $5 \mathrm{~mL} \mathrm{YPD} \mathrm{culture} \mathrm{with}$ a freshly grown colony of C. albicans strain CAl398 and grow at $20-30^{\circ} \mathrm{C}$ with shaking for $16 \mathrm{~h}$.

3. On the day of infection, harvest cells, wash twice in sterile endotoxin-free physiological saline, enumerate by hemocytometer, and adjust to a final concentration of $5 \times 10^{8} \mathrm{CFU} / \mathrm{mL}$ in sterile physiological saline.

4. Immunosuppress mice by intraperitoneal injection of cyclophosphamide $(150 \mathrm{mg} / \mathrm{kg})$.

5. Anesthetize mice by intraperitoneal injection of $80 \mu \mathrm{L}$ pentobarbital $(50 \mathrm{mg} / \mathrm{kg})$, shave an area of $4 \mathrm{~cm}^{2}$ on the lower back (Fig. la) to remove the fur, and then abrade the skin with sand paper until glistening (see Note 9).

6. Deposit $20 \mu \mathrm{L}$ of the C. albicans cell suspension on the abraded area.

7. Monitor infection every day for 7 days post infection by anesthetizing mice with $2.5 \%$ isoflurane and depositing $20 \mu \mathrm{L}$ coelenterazine $(500 \mu \mathrm{g} / \mathrm{mL})$ on the abraded skin area and imaging the animal dorsal side up in the IVIS-200 ${ }^{\mathrm{TM}}$ imaging system under anesthesia with $2.5 \%$ isoflurane (see Note 10 ).

8. For infections continuing for more than 3 days, perform a third immunosuppressive treatment by intraperitoneal injection of cyclophosphamide $(50 \mathrm{mg} / \mathrm{kg}$ ) on day 3 post infection.

1. One day prior to infection, inoculate a $5 \mathrm{~mL} \mathrm{YPD} \mathrm{culture} \mathrm{with}$ a freshly grown colony of C. albicans strain CAl398 and grow at $20-30^{\circ} \mathrm{C}$ with shaking for $16 \mathrm{~h}$.

2. On the day of infection, harvest cells, wash twice in sterile endotoxin-free physiological saline, enumerate by hemocytometer, and adjust to a final concentration of $10^{8} \mathrm{CFU} / \mathrm{mL}$ in sterile physiological saline.

3. Inoculate mice subcutaneously in the right thigh with $100 \mu \mathrm{L}$ of the C. albicans cell suspension.

4. After challenge, and every day post infection (see Note 11), inject mice subcutaneously with $100 \mu \mathrm{L}$ coelenterazine $(500 \mu \mathrm{g} / \mathrm{mL})$ and image animals in the IVIS-200 ${ }^{\mathrm{TM}}$ imaging system under anesthesia with $2.5 \%$ isoflurane (see Note 10 ).

1. Five days prior to infection, induce pseudo-estrus in mice by subcutaneous injection of $0.2 \mathrm{mg}$ estradiol valerate in $100 \mu \mathrm{L}$ sesame oil. Repeat injection weekly to maintain pseudo-estrus.

2. One day prior to infection, inoculate a $5 \mathrm{~mL}$ YPD culture with a freshly grown colony of C. albicans strain CA1398 and grow at $20-30^{\circ} \mathrm{C}$ with shaking for $16 \mathrm{~h}$. 
3. On the day of infection, harvest cells, wash twice in sterile endotoxin-free physiological saline, enumerate by hemocytometer, and adjust to a final concentration of $10^{9} \mathrm{CFU} / \mathrm{mL}$ in sterile physiological saline.

4. Anesthetize mice with $2.5 \%(\mathrm{v} / \mathrm{v})$ isoflurane gas (see Note 12).

5. Infect mice with $10 \mu \mathrm{L}$ of the $C$. albicans cell suspension administered from an Eppendorf $0.5-10 \mu \mathrm{L}$ mechanical pipette into the vaginal lumen, close to the cervix. To encourage vaginal contact and adsorption of fungal cells, hold mice head down for 1 min following inoculation.

6. Inoculate a $5 \mathrm{~mL}$ YPD culture with a freshly grown colony of C. albicans strain CA1398 and grow at room temperature with shaking for $16 \mathrm{~h}$.

7. On day 1 post infection, repeat steps $3 \mathbf{- 5}$.

8. Allow mice to recover for $24-48 \mathrm{~h}$, during which time the C. albicans vaginal infection will establish.

9. From day 4 , add $10 \mu \mathrm{L}$ coelenterazine $(5 \mathrm{mg} / \mathrm{mL})$ to the vaginal lumen and image animals in the IVIS $-200^{\mathrm{TM}}$ imaging system under anesthesia with $2.5 \%$ isoflurane (see Note 10 ).

\section{Notes}

1. Methods presented in this chapter only make use of strain CA1398. However, we also provide a list of the plasmids and strains which could be used in in vitro or in vivo experiments; these strains are available upon request.

2. Alternatively, black plates with transparent bottoms can be used, allowing simultaneous $\mathrm{OD}_{600}$ measurements.

3. Coelenterazine from different suppliers varies in quality. Highquality coelenterazine from Molecular Probes is used for in vitro experiments. Lower quality coelenterazine from Synchem is used for animal experiments. Coelenterazine derivatives with increased stability, such as ViviRen (Promega), have not proven different from standard coelenterazine in our hands.

4. Animal experiments should adhere to ethical rules in place in the laboratory/animal facility where they are performed. In our case, all animal experiments adhered to the EU Directive 86/609. Experiments were performed according to the guidelines of the European Convention for the Protection of Vertebrate Animals used for Experimental and other Scientific Purposes. (ETS No. 123). The protocol was approved by the Perugia University Ethics Committee (Comitato Universitario di Bioetica) (permit numbers 41-2005B and 34/2003-A). 
5. Luciferase activity can also be measured in a tube luminometer or detected by autoradiography (4).

6. Cell concentration in the assay can vary as it has been shown, using strain CA1398 expressing gLUC59 under the control of the $A C T I$ promoter, that luciferase activity varies linearly when using cell concentrations from $10^{3}$ to $10^{8}$ cells $/ \mathrm{mL}$. The use of identical cell concentrations for a given strain exposed to different conditions will facilitate comparisons between conditions.

7. Luciferase activity is expressed in relative luciferase units/cell. There is no requirement for a standard curve.

8. Groups of 4-6 animals are generally used for each strain tested.

9. Under these anesthesia conditions, mice remain asleep for $2 \mathrm{~h}$. The whole treatment-shaving, skin abrasion, and C. albicans cells deposition-takes a maximum of $2 \mathrm{~min}$ and does not require analgesia. Upon recovery from anesthesia, mice are active without signs of pain.

10. The duration for imaging varies according to the infection model. In our hands, using strain CA1398, expressing gLUC59 under the control of the $A C T 1$ promoter, imaging was carried out for 10-60 $\mathrm{s}$ in the cutaneous model of infection, $1-5 \mathrm{~min}$ in the subcutaneous model of infection, and $1-2 \mathrm{~min}$ in the vaginal candidiasis model. The imaging duration should be such that saturation at the site of infection is not achieved.

11. For the time of the studies, no adverse effects were observed due to repeated subcutaneous injection with coelenterazine.

12. Anesthesia is required for vaginal infection in order to inject the yeast suspension close to the cervix. To encourage vaginal contact and adsorption of fungal cells, mice are held head down for 1 min following inoculation (this procedure could be uncomfortable for mice when awake).

\section{Acknowledgements}

We are grateful to $\mathrm{Al}$ Brown for his contributions to the development of the luciferase reporter. Work in the laboratories of CdE and AV is supported by the European Commission (Galar Fungail 2 Marie Curie Research Training Network, MRTN-CT-2003-504148; FINSysB Marie Curie Initial Training Network, PITN-GA-2008-214004). Work in the laboratory of $\mathrm{CdE}$ is also supported by the Agence Nationale de la Recherche (KANJI, ANR-08-MIE-033-01). Brice Enjalbert was the recipient of a postdoctoral fellowship of the European Commission(GalarFungail2,MRTN-CT-2003-504148). $\mathrm{UZ}$ is the recipient of a postdoctoral fellowship of the program 
Carnot Maladies Infectieuses. SZ is the recipient of a postdoctoral fellowship of the European Commission (FINSysB, PITN-GA2008-214004).

\section{References}

1. Hutchens, M., and Luker, G. D. (2007) Applications of bioluminescence imaging to the study of infectious diseases, Cell Microbiol 9, 2315-2322.

2. Doyle, T. C., Nawotka, K. A., Kawahara, C. B., Francis, K. P., and Contag, P. R. (2006) Visualizing fungal infections in living mice using bioluminescent pathogenic Candida albicans strains transformed with the firefly luciferase gene, Microbial pathogenesis 40, 82-90.

3. Doyle, T. C., Nawotka, K. A., Purchio, A. F., Akin, A. R., Francis, K. P., and Contag, P. R. (2006) Expression of firefly luciferase in Candida albicans and its use in the selection of stable transformants, Microbial pathogenesis 40, 69-81.

4. Tannous, B. A., Kim, D. E., Fernandez, J. L., Weissleder, R., and Breakefield, X. O. (2005) Codon-optimized Gaussia luciferase cDNA for mammalian gene expression in culture and in vivo, Mol Ther 11, 435-443.

5. Moreno-Ruiz, E., Ortu, G., de Groot, P. W., Cottier, F., Loussert, C., Prevost, M. C., de Koster, C., Klis, F. M., Goyard, S., and d'Enfert, C. (2009) The GPI-modified proteins Pga59 and Pga62 of Candida albicans are required for cell wall integrity, Microbiology 155, 2004-2020.
6. Enjalbert, B., Rachini, A., Vediyappan, G., Pietrella, D., Spaccapelo, R., Vecchiarelli, A., Brown, A. J., and d'Enfert, C. (2009) A multifunctional, synthetic Gaussia princeps luciferase reporter for live imaging of Candida albicans infections, Infect Immun 77, 4847-4858.

7. Pietrella, D., Rachini, A., Torosantucci, A., Chiani, P., Brown, A. J., Bistoni, F., Costantino, P., Mosci, P., d'Enfert, C., Rappuoli, R., Cassone, A., and Vecchiarelli, A. (2010) A betaglucan-conjugate vaccine and anti-beta-glucan antibodies are effective against murine vaginal candidiasis as assessed by a novel in vivo imaging technique, Vaccine 28, 1717-1725.

8. d'Enfert, C., Vecchiarelli, A., and Brown, A. J. (2010) Bioluminescent fungi for real-time monitoring of fungal infections, Virulence 1 , 174-176.

9. Vediyappan, G., Rossignol, T., and d'Enfert, C. (2010) Interaction of Candida albicans biofilms with antifungals: transcriptional response and binding of antifungals to betaglucans, Antimicrob Agents Chemother 54, 2096-2111.

10. Murad, A. M., Lee, P. R., Broadbent, I. D., Barelle, C. J., and Brown, A. J. (2000) CIpl0, an efficient and convenient integrating vector for Candida albicans, Yeast 16, 325-327. 